\title{
Wykluczenie posła z posiedzenia Sejmu (art. 175 ust. 5 Regulaminu Sejmu) w świetle prac Komisji Regulaminowej i Spraw Poselskich
}

\section{Wprowadzenie}

Przedmiotem niniejszego artykułu jest prezentacja wyników badań nad dorobkiem Komisji Regulaminowej i Spraw Poselskich (dalej także „Komisja" ${ }^{1}$ w zakresie, w jakim dorobek ten obejmuje analizy okoliczności skorzystania przez Marszałka Sejmu z uprawnienia przysługującego mu na mocy art. 175 ust. 5 Regulaminu Sejmu ${ }^{2}$, to jest uprawnienia do wykluczenia posła z posiedzenia Sejmu. Analizy te zmierzały do oceny legalności decyzji Marszałka Sejmu o wykluczeniu posła z posiedzenia Sejmu przez Komisję na potrzeby wydania przez nią opinii dla Prezydium Sejmu (art. 175 ust. 6 Regulaminu Sejmu).

W powyższym przedmiocie Komisja dotychczas przeprowadziła pięć analiz, na posiedzeniach w dniach: 16 października 2002 r. (w związku z wykluczeniem posła Gabriela Janowskiego z posiedzenia Sejmu w tym samym dniu), 29 października 2002 r. (w związku z wykluczeniem

${ }^{1}$ Należy przy tym zaznaczyć, iż Uchwałą Sejmu Rzeczypospolitej Polskiej z dnia 9 VI 2016 r. w sprawie zmiany Regulaminu Sejmu Rzeczypospolitej Polskiej (M.P. 2016, poz. 512) zmieniono nazwę Komisji. Dotychczas jej nazwa brzmiała: „Komisja Regulaminowa i Spraw Poselskich”, a obecnie brzmi: „Komisja Regulaminowa, Spraw Poselskich i Immunitetowych". Ponieważ jednak dorobek Komisji, będący przedmiotem badań, których wyniki są prezentowane w niniejszym artykule, powstał w całości w okresie poprzedzającym omawianą nowelizację, to w niniejszym opracowaniu używane jest nazewnictwo przedmiotowego organu Sejmu sprzed jej przyjęcia.

${ }^{2}$ Uchwała Sejmu Rzeczypospolitej Polskiej z dnia 30 VII 1992 r. Regulamin Sejmu Rzeczypospolitej Polskiej (M.P. Nr 26, poz. 185 ze zm.), dalej także „Regulamin”, „RS”. 
kilku posłów Samoobrony z posiedzenia Sejmu w dniu 17 października 2002 r.), 18 lutego 2004 r. (w związku z wykluczeniem posła Antoniego Macierewicza z posiedzenia Sejmu w tym samym dniu), 17 czerwca 2005 r. (w związku z wykluczeniem posła Zbigniewa Nowaka z posiedzenia Sejmu w tym samym dniu) i 11 września 2015 r. (w związku z wykluczeniem posła Armanda Ryfińskiego z posiedzenia Sejmu w tym samym dniu). Analiz tych dotyczy niniejsze opracowanie.

Dla prawidłowego zaprezentowania wskazanych wyżej wyników badań konieczne jest uprzednie omówienie okoliczności będących przedmiotem analiz Komisji, a zatem przytoczenie przebiegu posiedzeń Sejmu w stosownym zakresie.

$\mathrm{Z}$ tego samego powodu konieczne jest też uprzednie odniesienie się do treści przepisu art. 175 Regulaminu Sejmu, jako że decyzje Marszałka Sejmu w przedmiocie wykluczeń posłów z posiedzeń Sejmu, jak i w konsekwencji analizy okoliczności ich podejmowania przez niego dokonywane przez Komisję następowały w trybie wskazanego przepisu. Omówienie treści całego art. 175 Regulaminu Sejmu jest uzasadnione faktem, iż treść ust. 5 tego artykułu, z którego wynika uprawnienie Marszałka Sejmu do wykluczenia posła z posiedzenia Sejmu, ściśle związana jest z treścią pozostałych jednostek redakcyjnych tego przepisu. W takiej też perspektywie normatywnej dokonywane były przez Komisję wskazywane powyżej analizy (na podstawie art. 175 ust. 6 zd. 1 RS).

Celem artykułu jest ocena prawidłowości opinii sformułowanych przez Komisję Regulaminową i Spraw Poselskich w sprawach odwołań posłów do Prezydium Sejmu od decyzji Marszałka Sejmu o wykluczeniu ich z posiedzenia izby niższej parlamentu. Ocena ta następować będzie w rezultacie oceny zasadności argumentów podnoszonych w ramach wyżej wskazywanych analiz - z punktu widzenia dogmatycznego. Celem artykułu jest również ocena zasadności podniesionego $\mathrm{w}$ toku jednej ze wzmiankowanych analiz postulatu modyfikacji treści art. 175 ust. 6 i 7 Regulaminu Sejmu w kierunku zmiany podmiotu posiadającego kompetencję do rozpatrzenia odwołania posła od decyzji Marszałka Sejmu o wykluczeniu posła z posiedzenia Sejmu (podmiotem tym miałoby być nie Prezydium Sejmu, ale Sejm). Ocena ta nastąpić ma również w drodze analogicznej oceny zasadności argumentacji na rzecz takiego rozwiązania, zaprezentowanej w toku prac Komisji.

W związku z wyżej wskazanymi celami postawić należy następujące hipotezy: (1) opinie sformułowane przez Komisję Regulaminową i Spraw Poselskich w sprawach odwołań posłów do Prezydium Sejmu od decyzji 
Marszałka Sejmu o wykluczeniu ich z posiedzenia izby niższej parlamentu są prawidłowe, (2) postulat modyfikacji treści art. 175 ust. 6 i 7 Regulaminu Sejmu w kierunku zmiany podmiotu posiadającego kompetencję do rozpatrzenia odwołania posła od decyzji Marszałka Sejmu o wykluczeniu posła z posiedzenia Sejmu z Prezydium Sejmu na Sejm jest zasadny.

Zaznaczyć należy w tym miejscu, że wspomniane wcześniej badania nad dorobkiem Komisji sprowadzały się właśnie do oceniania pod kątem dogmatycznym zasadności argumentacji podnoszonych w ramach jej analiz okoliczności skorzystania przez Marszałka Sejmu z uprawnienia do wykluczenia posła z posiedzenia Sejmu; te badania obejmowały także - w rezultacie - ocenianie prawidłowości opinii Komisji będących efektem wskazanych analiz i ocenienie zasadności postulatu zmiany podmiotu posiadającego kompetencję do rozpatrzenia odwołania posła od decyzji Marszałka Sejmu o jego wykluczeniu z posiedzenia Sejmu. Sformułowane w obu tych kwestiach oceny sa wynikami wskazanych badań.

Ramy artykułu nie pozwalają na szeroką analizę treści art. 175 Regulaminu Sejmu z punktu widzenia historycznego, komparatystycznego oraz dogmatycznego ${ }^{3}$. Rozważania o charakterze dogmatycznym obejmuje niniejszy artykuł tylko w takim zakresie, w jakim wynikaja one ze sprecyzowanych wyżej analiz Komisji Regulaminowej i Spraw Poselskich.

\section{Normatywna regulacja wykluczenia posła z posiedzenia Sejmu}

Kompetencja Marszałka Sejmu do wykluczenia posła z posiedzenia Sejmu uregulowana jest w art. 175 ust. 5 Regulaminu Sejmu. Kompetencja ta stanowi jedną z kompetencji porządkowych Marszałka Sejmu, przysługujących mu względem posłów w toku posiedzenia izby niższej parlamentu, a unormowanych w art. 175 ust. 2-5 Regulaminu Sejmu. Przepis ten w ust. 1 stanowi bowiem, że Marszałek Sejmu czuwa nad

${ }^{3}$ Rozważania o charakterze dogmatycznym w ograniczonym zakresie na ten temat podejmowali już niektórzy badacze, w szczególności: P. Czarny, B. Naleziński, Organy Sejmu Rzeczypospolitej Polskiej, Warszawa 2002, s. 38, 43, 59; M. Zubik, Organizacja wewnętrzna Sejmu Rzeczypospolitej Polskiej, Warszawa 2003, s. 156-160; K. Grajewski, Status prawny posła i senatora, Warszawa 2006, s. 149-150; idem, Odpowiedzialność posłów i senatorów na tle zasady mandatu wolnego, Warszawa 2009, s. 286-293. 
przestrzeganiem w toku obrad Regulaminu Sejmu oraz powagi i porządku na sali posiedzeń. W ust. 2-5 omawianego przepisu Regulaminu uchwałodawca przewidział wskazane kompetencje, mające na celu utrzymanie porządku na sali posiedzeń Sejmu. Zgodnie z treścią art. 175 ust. 2 Regulaminu Marszałek Sejmu może zwrócić uwagę posłowi, który w wystąpieniu swoim odbiega od przedmiotu obrad określonego w porządku dziennym, przywołaniem posła "do rzeczy”. Po dwukrotnym takim przywołaniu Marszałek może odebrać przemawiającemu głos. Marszałek Sejmu po uprzednim zwróceniu uwagi ma prawo przywołać posła "do porządku", jeżeli uniemożliwia on prowadzenie obrad (art. 175 ust. 3 RS). W przypadku niezastosowania się przez posła do polecenia Marszałka Sejmu, o którym mowa w ust. 3, Marszałek Sejmu ma prawo ponownie przywołać posła "do porządku", stwierdzając, że uniemożliwia on prowadzenie obrad (art. 175 ust. 4 Regulaminu). Marszałek ma prawo podjać decyzję o wykluczeniu posła z posiedzenia Sejmu, jeżeli poseł nadal uniemożliwia prowadzenie obrad i na tym samym posiedzeniu został już upomniany w trybie ust. 4; poseł wykluczony z posiedzenia Sejmu jest obowiązany natychmiast opuścić salę posiedzeń. Jeżeli poseł nie opuści sali posiedzeń, Marszałek Sejmu zarządza przerwę w obradach (art. 175 ust. 5 RS). W art. 175 ust. 6-7 Regulaminu Sejmu unormowano z kolei procedurę odwoławczą od decyzji Marszałka Sejmu o wykluczeniu posła z posiedzenia Sejmu. Wskazać należy, że od decyzji Marszałka Sejmu poseł może odwołać się do Prezydium Sejmu, które niezwłocznie rozstrzyga sprawę po zasięgnięciu opinii Komisji Regulaminowej i Spraw Poselskich. Do czasu ostatecznego rozstrzygnięcia sprawy poseł nie bierze udziału w posiedzeniu (art. 175 ust. 6 Regulaminu). O sposobie załatwienia odwołania Prezydium Sejmu niezwłocznie zawiadamia Sejm, jednak nie później niż na następnym posiedzeniu. Decyzja Prezydium Sejmu jest ostateczna (art. 175 ust. 7 RS).

W pierwotnej wersji Regulaminu Sejmu art. 175 oznaczony był numerem $101^{4} \mathrm{i}$ tak numerowany uległ on jednej nowelizacji. Art. 101 Regulaminu zmieniony został, w odniesieniu do omawianego artykułu, uchwałą Sejmu Rzeczypospolitej Polskiej z dnia 8 maja 2002 r. w sprawie zmiany Regulaminu Sejmu Rzeczypospolitej Polskiej ${ }^{5}$. Korekta treści art. 101 RS

${ }^{4}$ Zmiana numeracji z art. 101 na art. 175 Regulaminu nastąpiła w dniu 15 VI 2002 r. (zob. Obwieszczenie Marszałka Sejmu Rzeczypospolitej Polskiej z dnia 29 V 2002 r. w sprawie ogłoszenia jednolitego tekstu uchwały Sejmu Rzeczypospolitej Polskiej Regulamin Sejmu Rzeczypospolitej Polskiej (M.P. Nr 23, poz. 398).

${ }^{5}$ M.P. Nr 18, poz. 304. 
obejmowała jego ust. 3-5 i sprowadzała się zasadniczo do wprowadzenia przesłanki „uniemożliwiania prowadzenia obrad" przez posła (w miejsce przesłanek „zakłócenia porządku obrad” i „dopuszczenia się ciężkiego naruszenia porządku obrad" przez niego) jako przesłanki dopuszczalności skorzystania przez Marszałka Sejmu z instrumentów dyscyplinujących parlamentarzystę na sali posiedzeń Sejmu. Postulaty modyfikacji treści omawianego artykułu zgłaszane były także w toku prac Komisji Nadzwyczajnej do spraw zmian w Regulaminie Sejmu, obradującej w IV kadencji Sejmu. Omawiane postulaty formułowane były głównie przez Klub Parlamentarny Sojuszu Lewicy Demokratycznej i obejmowały zasadniczo zmiany w art. $175 \mathrm{RS}$ w kierunku wprowadzenia możliwości wykluczenia posła na okres dłuższy niż jedno posiedzenie Sejmu w sytuacji jego uprzedniego wykluczenia, a także nieopuszczenia przez niego sali posiedzeń w związku z jego wykluczeniem ${ }^{6}$.

Warto $\mathrm{w}$ tym miejscu zaznaczyć, że $\mathrm{w}$ doktrynie prawa konstytucyjnego nie budzi wątpliwości dopuszczalność wykluczenia deputowanego z posiedzenia Sejmu z punktu widzenia postanowień ustawy zasadniczej. W szczególności, zdaniem A. Szmyta, „[...] nie budzi [...] zastrzeżeń konstytucyjnych co do swej istoty instytucja wykluczenia posła [...] z posiedzenia, jeśli uniemożliwia on prowadzenie obrad. Oparciem dla instytucji «wykluczenia» jest przepis art. 112 Konstytucji, z którego m.in. wynika dla Sejmu nakaz takiego zorganizowania (regulaminowo) swoich prac, by mogły one być rzeczywiście prowadzone. Konstytucyjne zasady sprawowania mandatu poselskiego muszą być rozumiane łącznie $\mathrm{z}$ art. 112 Konstytucji, w stosownym więc zakresie «miarkowane» potrzebami «dyscyplinowania» posłów"7.

\section{Wykluczenie posła Gabriela Janowskiego z posiedzenia Sejmu w dniu 16 października 2002 r.}

Na posiedzeniu Sejmu w dniu 16 października 2002 r., po przedstawieniu przez marszałka Marka Borowskiego porządku dziennego posiedzenia Sejmu, poseł Antoni Macierewicz wystąpił z wnioskiem o uzupełnienie tego porządku o punkt: Informacja rządu Rzeczypospolitej Polskiej o sytuacji w polskim hutnictwie. Następnie poseł Gabriel

${ }^{6}$ Zob. szerzej A. Szmyt, Elementy praktyki sejmowej pod rzadami Konstytucji RP (1997-2007), Gdańsk 2008, s. 104-108.

${ }^{7}$ Ibidem, s. 105. 
Janowski zwrócił uwagę na fakt sprzedaży stołecznego przedsiębiorstwa energetycznego STOEN niemieckiemu koncernowi RWE jako decyzję sprzeczną z polską racją stanu. Na uwagę marszałka, że sprawa jest znana, odparł, iż jest przeciwnie. Marszałek stwierdził, że poseł nie musi tego uzasadniać, a następnie wezwał go do złożenia wniosku. Poseł wnosił o to, by premier (wówczas Leszek Miller) złożył posłom jednoznaczne oświadczenie, iż wycofa się ze wskazanej wyżej sprzedaży, a także nie sprzeda przedsiębiorstw energetycznych w innych miastach, wymienionych przez posła, które wedle niego miały być sprzedane głównie innemu niemieckiemu koncernowi (EON). Przeciwne zachowanie Prezesa Rady Ministrów miałoby skutkować utratą przez Polskę suwerenności energetycznej. Gdy poseł kontynuował uzasadnianie swojego wniosku, marszałek poprosił go o to, by odstąpił już od wygłaszania przemówienia, potem wezwał do zakończenia wystąpienia, a następnie zwrócił mu uwagę, że uniemożliwia mu on prowadzenie obrad. Ponieważ poseł kontynuował wywód, marszałek poprosił go o zakończenie wystąpienia i opuszczenie mównicy pod rygorem wyłączenia mikrofonu, co nastąpiło. Wobec faktu, że poseł kontynuował wypowiedź przy wyłączonym mikrofonie, marszałek po raz kolejny poprosił posła o opuszczenie mównicy, a następnie stwierdził, iż uzasadnił on już swój wniosek. Poprosił go też o zajęcie miejsca na sali. Poseł jednak kontynuował wystąpienie, co spowodowało, że marszałek znów poprosił posła o zejście z mównicy i zajęcie miejsca (na sali). Ten jednak odmówił, żądając od marszałka deklaracji wyjaśnienia sprawy. Gdy poseł kontynuował wypowiedź, marszałek zwrócił mu uwage i dwukrotnie przywołał go do porządku. Poseł oznajmił, że przywołanie do porządku przyjmuje do wiadomości. W reakcji na to marszałek po raz kolejny nakazał mu opuścić mównicę i zająć miejsce (na sali). W odpowiedzi na to poseł stwierdził, że opuści mównicę pod określonym warunkiem, co marszałek ocenił jako niedopuszczalne i ponownie sformułował prośbę o opuszczenie mównicy. Marszałek poinformował także posła jeszcze raz, iż uniemożliwia mu on prowadzenie obrad. Gdy poseł przyznał powyższe i próbował swoje zachowanie uzasadnić, marszałek ponownie przywołał go do porządku i stwierdził, że uniemożliwia mu on prowadzenie obrad. Poseł przyjął to do wiadomości, lecz jednocześnie zaznaczył, że nie odstąpi. Wówczas marszałek podjął decyzję o wykluczeniu go z posiedzenia Sejmu i zarządził przerwę ${ }^{8}$.

${ }^{8}$ Wypowiedzi na posiedzeniach Sejmu RP IV kadencji, 32. posiedzenie Sejmu w dniu 16 X 2002 r., http://orka2.sejm.gov.pl/Debata4.nsf (dostęp: 22 X 2016). 
Zarzut odwołania wniesionego przez posła Gabriela Janowskiego od wskazanej wyżej decyzji marszałka do Prezydium Sejmu sprowadzał się do braku zadośćuczynienia przez marszałka dyspozycji art. 175 ust. 2 Regulaminu Sejmu. W toku obrad Komisji Regulaminowej i Spraw Poselskich, której zadaniem było zaopiniowanie dla Prezydium Sejmu wskazanego odwołania, głosy polemiczne dotyczące wskazanego zarzutu zgłosili: przedstawiciel Biura Legislacyjnego Kancelarii Sejmu ${ }^{9}$ i poseł Roman Giertych. Zdaniem pierwszego z nich procedura, która zastosował marszałek, była zgodna $\mathrm{z}$ art. $175 \mathrm{RS}$. W jego opinii ratio legis art. 175 ust. 2 Regulaminu sprowadza się do przywołania posła "do rzeczy" w sytuacji, w której poseł zabiera głos w jakimś punkcie porządku dziennego obrad Sejmu i mówi nie na temat, natomiast w tym stanie faktycznym poseł zabrał głos poza porządkiem dziennym. W jego opinii zatem w zaistniałej sytuacji przepis art. 175 ust. 2 RS nie znajduje zastosowania. Niezależnie od tego wskazał on, że zanim marszałek odebrał głos posłowi, dwukrotnie prosił o zakończenie wystąpienia, w związku z czym procedura zapisana w ust. 2 powołanego wyżej przepisu została wyczerpana.

W odpowiedzi na to stanowisko poseł Roman Giertych wskazał, że, jego zdaniem, z punktu widzenia treści art. 175 ust. 2 Regulaminu wystąpienie posła Gabriela Janowskiego było „wystąpieniem”. Było to, według niego, "[...] wystąpienie formalne w trybie regulaminowym, $\mathrm{w}$ ramach obrad, jednak nie było to wystąienie w trakcie porządku obrad, ponieważ wtedy jeszcze porządek obrad nie został ustalony". W związku z powyższym, według tego posła, marszałek nie wypełnił przesłanek art. 175 ust. 2 RS, gdyż nie użył słów "do rzeczy”, jak i expressis verbis nie odebrał przemawiającemu głosu. Poseł Roman Giertych zauważył także, iż "(d)opiero po dwukrotnym przywołaniu posła do rzeczy marszałek może przywołać posła do porządku", wskazując, że art. 175 ust. 3 Regulaminu uzależnia skorzystanie przez marszałka z prawa do przywołania posła "do porządku” od uprzedniego "zwrócenia uwagi” jego osobie, przy czym sposób zwrócenia uwagi opisany jest w ust. 2 omawianego przepisu, a sprowadza się do przywołania posła "do rzeczy". Przepis ust. 3 odwołuje się zatem do postanowienia ust. 2. Wskazany poseł zauważył także, iż skoro z art. 175 ust. 2 wynika jednoznacznie, że marszałek Sejmu ma dwa razy wypowiedzieć słowa "do rzeczy", to nie można powiedzieć, że zwrócenie posłowi uwagi w inny sposób wyczerpuje dyspozycję wskazanego przepisu; nie podlega on zatem wykładni

\footnotetext{
${ }^{9}$ Nie zostało ujawnione imię i nazwisko tej osoby.
} 
rozszerzającej ze względu na regulaminowe obostrzenia obejmujące procedurę zmierzającą do wykluczenia posła, co może mieć istotne znaczenie dla przebiegu posiedzenia Sejmu.

W formie repliki przedstawiciel Biura Legislacyjnego Kancelarii Sejmu wskazał, iż Biuro „[...] nie stawiało tezy, że wystąpienie posła Gabriela Janowskiego nie było «wystąpieniem». Ono było «wystąpieniem» i to nie budzi wątpliwości, ale nie było wystąpieniem, w którym poseł Gabriel Janowski odbiegał od przedmiotu obrad określonego w porządku dziennym”. Wskazał także, iż "(z)wrócenie przez Marszałka Sejmu uwagi posłowi było wyczerpane. Trudno oczekiwać, aby Marszałek Sejmu upominał występującego posła słowami «do rzeczy», ponieważ nie było to wystąpienie $\mathrm{w}$ przedmiocie punktu porządku dziennego. Padały natomiast inne stwierdzenia: "proszę zakończyć wystąpienie», «panie pośle, zwracam panu uwagę, że uniemożliwia pan prowadzenie obrad». Zdaniem Biura Legislacyjnego Kancelarii Sejmu ta procedura została wyczerpana".

W rezultacie przeprowadzonej dyskusji Komisja przyjęła opinię wskazująca, że marszałek wyczerpał regulaminową procedurę wynikającą z art. 175 ust. 2-5 Regulaminu Sejmu, a zatem stwierdziła prawidłowość zachowania marszałka ${ }^{10}$.

W celu oceny zasadności sformułowanych wyżej argumentów należy podnieść, co następuje. $W$ istocie zauważyć wypada, że w świetle treści art. 175 ust. 2 Regulaminu Sejmu Marszałek może zwrócić posłowi uwage przywołaniem go "do rzeczy” nie w trakcie każdego jego "wystąpienia", ale tylko takiego "wystąpienia”, w którym odbiega on od przedmiotu obrad określonego w porządku dziennym. Oczywiście, należy zgodzić się z poglądem, wynikającym z wykładni systemowej wskazanego przepisu, iż ratio legis omawianego przepisu sprowadza się do przywołania posła "do rzeczy" w sytuacji, w której poseł zabiera głos w jakimś punkcie porządku dziennego obrad Sejmu i mówi nie na temat. Wskazać jednak należy, że z literalnego brzmienia art. 175 ust. 2 RS można wywodzić, iż poseł może w swoim wystąpieniu odbiegać od przedmiotu obrad określonego w porządku dziennym, zabierając głos poza jakimkolwiek punktem porządku dziennego, a zatem przemawiając $\mathrm{w}$ jakimkolwiek innym trybie regulaminowym (np. zgłaszając wniosek formalny, dokonując sprostowania błędnie zrozumianego

${ }^{10}$ Posiedzenie numer 30. Komisji Regulaminowej i Spraw Poselskich w dniu 16 X 2002 r., http://orka.sejm.gov.pl/SQL.nsf/Main4?OpenForm\&RSP (dostęp: $22 \times 2016)$. 
lub nieściśle przytoczonego stwierdzenia mówcy, zgłaszając wniosek o odroczenie dyskusji - art. 184 ust. 1 i 7 RS) bądź nawet (w ekstremalnych wypadkach) wypowiadając się samowolnie, tj. bez zezwolenia przewodniczącego obradom. Z punktu widzenia czysto formalnego, na gruncie art. 175 RS, treść takich wystąień również mogłaby być uznana za "odbiegającą od przedmiotu obrad określonego w porządku dziennym". Wskazać jednak należy, że wykładnia taka, jako zmierzająca ad absurdum, musi zostać odrzucona, zaś uznana za zasadną winna zostać wyżej wskazana wykładnia o charakterze systemowym.

Rozumując systemowo, jak wyżej, wskazać należy, iż oczywiście zwrócić uwagę posłowi Marszałek powinien regulaminowo określonymi słowami: „do rzeczy”. W tym zakresie przyjąć należy zatem wykładnię zawężająca, a nie rozszerzająca, nie pozostawiając Marszałkowi uprawnienia do zwracania uwagi posłowi innymi słowami niż wskazane.

Rozważyć należy też kwestię, czy w istocie „uprzednie zwrócenie uwagi", o którym mowa w art. 175 ust. 3 Regulaminu, będące przesłanką "przywołania posła do porządku”, odpowiada "zwróceniu uwagi”, o którym mowa w art. 175 ust. 2 RS, a zatem polegającemu na "przywołaniu posła "do rzeczy»". Rozstrzygając wskazany problem, należy w pierwszej kolejności odwołać się do wykładni językowej. Jej wyniki pozwalają stwierdzić, że "uprzednie zwrócenie uwagi", o którym mowa w art. 175 ust. 3 Regulaminu, obejmuje zwrócenie posłowi uwagi, iż uniemożliwia on prowadzenie obrad, a nie "przywołanie posła «do rzeczy»". Wynika to z faktu, że "przywołanie posła do porządku”, które ma być poprzedzone "zwróceniem uwagi", następuje właśnie w sytuacji uniemożliwiania przez posła prowadzenia obrad. „Zwrócenie uwagi” posłowi przed "przywołaniem posła do porządku” musi zatem dotyczyć tego właśnie rodzaju zachowania posła. Z punktu widzenia językowego odwołanie się przy interpretacji regulaminowego zwrotu „uprzedniego zwrócenia uwagi" do tej samej jednostki redakcyjnej (art. 175 ust. 3 Regulaminu) jest zatem wystarczające do dokonania jego wykładni, wobec czego niezasadne jest ustalanie treści wskazanego zwrotu, biorąc pod uwagę treść innej jednostki redakcyjnej (art. 175 ust. 2 RS). Również z punktu widzenia systemowego niezasadne jest odwoływanie się przy interpretacji omawianego postanowienia regulaminowego do treści art. 175 ust. 2 Regulaminu. Wskazać bowiem należy, że kompetencje porządkowe Marszałka, przewidziane w art. 175 ust. 2 i 3, mają zupełnie odmienny charakter. Pierwsza z nich wiąże się bowiem z wypowiedzią posła "nie na temat" w ramach określonego punktu porządku dziennego, 
natomiast druga - z uniemożliwianiem przez posła prowadzenia obrad, co w pierwszym wypadku nie następuje.

W rezultacie stwierdzić należy zatem prawidłowość opinii Komisji.

\section{Wykluczenie posłów: Renaty Beger, Alfreda Budnera, Krzysztofa Filipka, Andrzeja Leppera, Stanisława Łyżwińskiego, Tadeusza Szukały, Marii Zbyrowskiej i Józefa Żywca z posiedzenia Sejmu w dniu 17 października 2002 r.}

Przebieg posiedzenia Sejmu w dniu 17 października 2002 r. miał związek $\mathrm{z}$ przebiegiem posiedzenia izby niższej parlamentu $\mathrm{w}$ dniu poprzednim. Wskazać bowiem należy, że po wykluczeniu przez Marszałka z posiedzenia Sejmu posła Gabriela Janowskiego i zarządzeniu przerwy nie opuścił on sali posiedzeń Sejmu, przebywając w niej, wraz z kilkoma innymi posłami Ligi Polskich Rodzin oraz niektórymi posłami Samoobrony i Polskiego Stronnictwa Ludowego, do późnych godzin nocnych. W nocy, po podjęciu kilku prób przekonania wskazanego posła do dobrowolnego opuszczenia sali posiedzeń Sejmu, marszałek podjął decyzję o usunięciu posła z tej sali przez strażników Straży Marszałkowskiej. Ponadto podjęta została decyzja o zmianie porządku dziennego obrad Sejmu w dniu następnym (17 października 2002 r.) poprzez uzupełnienie go o punkt dotyczący prywatyzacji przedsiębiorstwa STOEN. Realizacja wskazanego punktu, jako pierwszego punktu porządku dziennego, rozpoczęta została od przedstawienia sprawozdania. W dalszej części posiedzenia przystąpiono do debaty, którą otworzył minister Skarbu Państwa Wiesław Kaczmarek. Wystąpienie jego przerywać rozpoczęli jednak posłowie Samoobrony, protestując przeciwko „opowiadaniu bzdur" i wzywając ministra do opuszczenia mównicy i udostępnienia jej im - gromadząc się na i wokół mównicy. Wicemarszałek Tomasz Nałęcz, przerwawszy wystąpienie ministra, wezwał wskazanych posłów do zachowania spokoju i powrócenia na miejsce (na sali). Kiedy poseł Andrzej Lepper zaczął domagać się pisemnego przyrzeczenia, że STOEN nie zostanie sprywatyzowany, i zasugerował, iż możliwe jest wymuszenie takiej czynności w drodze analogii do siłowego wyprowadzenia posła Gabriela Janowskiego z sali posiedzeń Sejmu w dniu poprzednim, wicemarszałek przywołał posłów Samoobrony do rzeczy, a następnie do porządku. Po replice posła Andrzeja Leppera słowami: "(n)iech pan sobie przywołuje", wicemarszałek stwierdził, że wskazani 
posłowie uniemożliwiają mu prowadzenie posiedzenia. W odpowiedzi na to poseł Andrzej Lepper wskazał: „(t)ak jest. Zdajemy sobie w pełni z tego sprawę, musi pan wiedzieć, w pełni. Niech pan nas nie straszy". Następnie wicemarszałek wymienił z nazwiska posłów Samoobrony, stwierdzając, że uniemożliwiają mu oni prowadzenie posiedzenia Sejmu i przywołał ich do porządku, a gdy ci nie zareagowali, przywołał ich do porządku powtórnie. Gdy poseł Andrzej Lepper nadal domagał się odwołania prywatyzacji STOEN-u i próbował uzasadniać swój postulat, wicemarszałek po raz trzeci przywołał posłów Samoobrony do porządku w związku z uniemożliwianiem mu przez nich prowadzenia posiedzenia Sejmu. Wskazał przy tym, że czyni to pozaregulaminowo $z$ uwagi na to, iż wystarczy dwukrotne użycie tej formuły. Ostrzegł także posłów Samoobrony, iż za chwilę wykluczy ich z posiedzenia Sejmu. Gdy poseł Andrzej Lepper kontynuował swój wywód, wicemarszałek sformułował powyższe ostrzeżenia ponownie, na co wskazany poseł odpowiedział: „(t)o proszę bardzo, ma pan prawo”. Wobec powyższego wicemarszałek, stwierdzając, iż nie ma innej możliwości, wykluczył wymienionych wcześniej z nazwiska posłów Samoobrony z posiedzenia Sejmu, a następnie zarządził przerwę $\mathrm{w}$ obradach ${ }^{11}$.

Zarzut odwołania posłów Samoobrony od wyżej wskazanej decyzji wicemarszałka, opiniowanego dla Prezydium Sejmu przez Komisję Regulaminową i Spraw Poselskich, sprowadzał się do braku sformułowania przez wicemarszałka podstawy prawnej podjęcia decyzji o wykluczeniu posłów tej partii z posiedzenia Sejmu, wynikającej z Regulaminu Sejmu. Spośród wypowiedzi członków Komisji w przedmiocie sprecyzowanego wyżej zarzutu warto wskazać w szczególności na wypowiedzi posłów Teresy Jasztal i Wacława Martyniuka (przewodniczącego Komisji). Posłanka T. Jasztal zwróciła uwagę na świadomość posłów Samoobrony co do podstawy prawnej działania wicemarszałka, przejawiającej się w szczególności w słownym przyznaniu legalności jego zachowań („Pan ma prawo nas wykluczyć"), zwłaszcza w perspektywie zastosowania przepisów dotyczących wykluczenia posła z posiedzenia Sejmu zaledwie w dniu poprzednim. Według niej zachowania posłów Samoobrony jako zgodnego z prawem nie legitymizował brak powołania przez wicemarszałka podstawy prawnej ich wykluczenia z posiedzenia Sejmu. Z kolei poseł W. Martyniuk zwrócił uwagę nadto na obywatelski,

${ }^{11}$ Wypowiedzi na posiedzeniach Sejmu RP IV kadencji, 32. posiedzenie Sejmu w dniu 17 X 2002 r., http://orka2.sejm.gov.pl/Debata4.nsf (dostęp: 22 X 2016). 
a w szczególności poselski obowiązek znajomości i przestrzegania prawa, co w szczególności (w odniesieniu do posłów) dotyczy Regulaminu Sejmu. Przewodniczący Komisji wskazał również, iż "(z)apis art. 175 ust. 5, odnoszący się do trybu wykluczenia posła przez Marszałka Sejmu z posiedzenia Sejmu, nie zawiera obowiązku podania podstawy prawnej tej decyzji". W rezultacie przeprowadzonej dyskusji Komisja przyjęła opinię stwierdzającą bezzasadność złożonego odwołania ${ }^{12}$.

W celu oceny zasadności sformułowanych wyżej argumentów należy podnieść, co następuje. Niezależnie od świadomości posła w zakresie treści art. 175 ust. 5 Regulaminu Sejmu, istnieje konieczność rozważenia, czy w istocie dla skuteczności wykluczenia posła z posiedzenia Sejmu konieczne jest wskazanie przez marszałka expressis verbis podstawy prawnej tego działania, tj. oznaczenia numerycznego wskazanego wyżej przepisu.

Jako punkt wyjścia dla rozstrzygnięcia postawionego problemu należy wskazać treść art. 7 Konstytucji, wyrażającego dwie zasady: legalizmu - wymagającego działania na podstawie prawa oraz praworządności - wymagającej przestrzegania prawa ${ }^{13}$. Zgodnie z zasadą legalizmu, jak wskazuje B. Banaszak, „[...] kompetencja (realizująca ją działalność) każdego organu władzy publicznej powinna opierać się na wyraźnie sformułowanym przepisie prawnym. Oznacza to, że w państwie praworządnym wszelka działalność władcza wymaga podstaw prawnych, tzn. legitymacji w prawnie nadanym upoważnieniu do działania"14. Z kolei, jak zaznacza W. Sokolewicz, , [k]onstytucyjny wymóg podstawy prawnej jest równoznaczny z żądaniem, by taka podstawa faktycznie istniała, a nie - by była obowiązkowo powołana w opartym na niej rozstrzygnięciu. Obowiązek powołania podstawy prawnej w akcie stosowania prawa (np. decyzji) - mogą nakładać przepisy ustawowe, pozakonstytucyjne (np. odnoszące się do postępowania administracyjnego)"15. Trzeba zatem wskazać, że jeżeli dla skuteczności wykluczenia posła z posiedzenia Sejmu konieczne byłoby wskazanie przez marszałka expressis verbis podstawy prawnej tego działania, tj. oznaczenia numerycznego

${ }^{12}$ Posiedzenie numer 31 Komisji Regulaminowej i Spraw Poselskich w dniu 29 X 2002 r., http://orka.sejm.gov.pl/SQL.nsf/Main4?OpenForm\&RSP (dostęp: 22 X 2016).

${ }^{13}$ Tak P. Tuleja, Komentarz do art. 7 Konstytucji, w: Konstytucja RP, t. 1: Komentarz. Art. 1-86, pod red. M. Safjana, L. Boska, Warszawa 2016, s. 305.

${ }^{14}$ B. Banaszak, Konstytucja Rzeczypospolitej Polskiej. Komentarz, Warszawa 2012, s. $77-78$.

${ }^{15}$ W. Sokolewicz, Komentarz do art. 7 Konstytucji, w: Konstytucja Rzeczypospolitej Polskiej. Komentarz. Część I, pod red. L. Garlickiego, Warszawa 2007, s. 10. 
przepisu art. 175 ust. 5 RS, to obowiązek podania wskazanej podstawy prawnej musiałby wynikać z treści tegoż przepisu. Taki obowiązek w art. 175 ust. 5 Regulaminu nie jest jednak ujęty. Należy zatem, w całej rozciągłości, zgodzić się z twierdzeniem sformułowanym $w$ tym zakresie przez przewodniczącego Komisji Regulaminowej i Spraw Poselskich i negatywnie rozstrzygnąć postawiony wyżej problem.

W konkluzji stwierdzić trzeba zatem prawidłowość opinii Komisji.

\section{Wykluczenie posła Antoniego Macierewicza z posiedzenia Sejmu w dniu 18 lutego 2004 r.}

Na posiedzeniu Sejmu w dniu 18 lutego 2004 r. poseł Antoni Macierewicz, po zgłoszeniu chęci zaprezentowania wniosku formalnego, poruszył sprawę konieczności podjęcia przez Sejm przed dniem 1 maja 2004 r. (a zatem data przystąpienia Polski do Unii Europejskiej) uchwały mającej na celu zapobieżenie skutecznemu dochodzeniu roszczeń odszkodowawczych Niemiec wobec Polski po tej dacie. Wskazał, iż uzyskał zapewnienie od wicemarszałka Janusza Wojciechowskiego, że sprawa ta zostanie rozpatrzona przez połączone Komisje: Sprawiedliwości i Praw Człowieka oraz Spraw Zagranicznych, w dniu 18 lutego 2004 r., tak aby sprawa mogła zostać rozstrzygnięta na bieżącym posiedzeniu Sejmu. Wicemarszałek Tomasz Nałęcz poinformował posła, że sprawa trafiła do komisji i jest załatwiana, a nadto iż poruszona przez niego kwestia nie wyczerpuje trybu zabrania głosu w kwestii formalnej. Wystąpienie wskazanego wyżej posła uzupełnił poseł Antoni Stryjewski, który prosił wicemarszałka o wskazanie terminu odbycia posiedzenia połączonych komisji. Ten poinformował go, że terminy posiedzeń komisji ustalają ich prezydia, natomiast marszałek może jedynie zwrócić się do tych komisji o przyspieszenie prac - i takie działania marszałek Marek Borowski właśnie podejmuje. Po przerwie ponownie zabrał głos, bez udzielenia mu go przez wicemarszałka, poseł Antoni Macierewicz, który zwrócił uwagę, że nie otrzymał on informacji, kiedy odbędzie się posiedzenie komisji. Wicemarszałek przywołał go do porządku i poinformował, że ma wyłączony mikrofon. Gdy poseł kontynuował wypowiedź, wicemarszałek uczynił to ponownie. Gdy poseł ponowił pytanie o termin posiedzenia połączonych komisji, wicemarszałek stwierdził, że udzielił już odpowiedzi na to pytanie, i zapowiedział przystąpienie do procedury wykluczającej posła z obrad. W toku dalszej wymiany zdań pomiędzy 
posłem a wicemarszałkiem pierwszy kilkukrotnie powtarzał pytanie bądź to o termin wspólnego posiedzenia komisji, bądź to o termin uzyskania przez wicemarszałka informacji w tym przedmiocie. $Z$ kolei drugi najpierw oznajmił, że poseł uniemożliwia mu prowadzenie obrad, następnie dwukrotnie przywołał go do porządku, a ostatecznie wykluczył go z posiedzenia Sejmu. Poseł zareagował słowami: „(w) porządku”, a wicemarszałek poprosił go o opuszczenie sali posiedzeń. Gdy mimo to poseł podjął próbę zadania pytania po raz kolejny, wicemarszałek zarządził przerwę $\mathrm{w}$ obradach ${ }^{16}$.

Na posiedzeniu Komisji Regulaminowej i Spraw Poselskich, obradującej w trybie art. 175 ust. 6 Regulaminu Sejmu w dniu wykluczenia przez wicemarszałka posła Antoniego Macierewicza z posiedzenia Sejmu, a zatem w dniu 18 lutego 2004 r., ekspert Komisji Janusz Mordwiłko zwrócił uwagę na to, że w istocie wskazany poseł poprzez zachowanie polegające na nieopuszczaniu (okupowaniu, blokowaniu) mównicy zakłócił porządek obrad posiedzenia Sejmu.

Na posiedzeniu Komisji głos zabrał również wicemarszałek Sejmu Tomasz Nałęcz, który podjął decyzję o wykluczeniu posła Antoniego Macierewicza z posiedzenia Sejmu. Zwrócił uwagę na fakt wprowadzenia w błąd przewodniczącego obradom Sejmu przez wskazanego posła, który zgłosił się do zabrania głosu w sprawie formalnej, a wypowiedział się w kwestii merytorycznej - poza porządkiem dziennym posiedzenia Sejmu. Poseł Antoni Macierewicz na posiedzeniu Komisji bronił się, że w istocie nie był świadom, iż wypowiada się w sprawie merytorycznej, a nie w kwestii formalnej. W rezultacie przeprowadzonej dyskusji Komisja przyjęła opinię stwierdzającą bezzasadność złożonego odwołania ${ }^{17}$.

W celu oceny zasadności sformułowanych wyżej argumentów należy podnieść, co następuje. Zauważyć warto, że w istocie regulaminowy zwrot "uniemożliwianie prowadzenia obrad” ma charakter nieostry, pozwalający na zakwalifikowanie rozmaitych zachowań poselskich jako takich, które stanowią podstawę do skorzystania przez Marszałka Sejmu z kompetencji porządkowych przewidzianych w art. 175 Regulaminu, w tym z uprawnienia do wykluczenia posła z posiedzenia Sejmu (art. 175 ust. 5). Sposób ujęcia wskazanej przesłanki skorzystania przez

${ }^{16}$ Wypowiedzi na posiedzeniach Sejmu RP IV kadencji, 68. posiedzenie Sejmu w dniu 18 II 2004 r., http://orka2.sejm.gov.pl/Debata4.nsf (dostęp: 22 X 2016).

${ }_{17}$ Posiedzenie numer 77 Komisji Regulaminowej i Spraw Poselskich w dniu 18 II 2004 r., http://orka.sejm.gov.pl/SQL.nsf/Main4?OpenForm\&RSP (dostęp: $22 \times 2016)$. 
przewodniczącego obradom ze wskazanych kompetencji niewątpliwie niesie za sobą zagrożenie w zakresie prawidłowości kwalifikacji danego zachowania posła jako „uniemożliwiającego prowadzenie obrad” i ryzyko dowolności tej kwalifikacji przez Marszałka Sejmu, w zależności od jego oceny czy też uznania. Odmienne jednak jej ujęcie sprowadzałoby się do zupełnie zbędnej kazuistyki.

Niezależnie od powyższego, w sposób oczywisty jako „uniemożliwianie prowadzenia obrad" należy zakwalifikować nieopuszczanie (okupowanie, blokowanie) mównicy mimo kierowanych do posła przez Marszałka Sejmu poleceń jej opuszczenia. Wskazane zachowanie uniemożliwia bowiem Marszałkowi Sejmu, udzielającemu głosu posłom, realizację poszczególnych punktów porządku dziennego obrad Sejmu, co polega na formułowaniu wypowiedzi przez posłów.

Podstawą do wydania posłowi przez przewodniczącego obradom Sejmu polecenia opuszczenia mównicy jest w szczególności okoliczność przekroczenia przez posła czasu na zaprezentowanie wniosku formalnego. Okoliczność taka nie jest samoistnie „uniemożliwianiem prowadzenia obrad", lecz tylko jej konsekwencją w postaci fizycznej obecności posła na mównicy - wbrew woli przewodniczącego obradom ${ }^{18}$.

W rezultacie stwierdzić należy prawidłowość opinii Komisji.

\section{Wykluczenie posła Zbigniewa Nowaka z posiedzenia Sejmu w dniu 17 czerwca 2005 r.}

Na początku posiedzenia izby niższej parlamentu w dniu 17 czerwca 2005 r. poseł Zbigniew Nowak zajął miejsce przy mównicy w koszulce z napisami „Kaczyński ... przestępcą?”, „Dość ... cenzury. Art. 54 Konstytucji”, demonstrując także drugą koszulkę z napisami "www.raportnowaka.pl”, „Art. 61 Konstytucji”. Marszałek Włodzimierz Cimoszewicz zwrócił posłowi uwagę, że jego zachowanie uwłacza powadze Sejmu i za chwilę prawdopodobnie doprowadzi do konfliktu uniemożliwiającego mu prowadzenie obrad. Zwrócił się do niego także o opuszczenie zajmowanego miejsca, czego wykonania poseł odmówił. Wobec powyższego marszałek zwrócił mu uwagę, że zakłóca obrady Sejmu

${ }^{18}$ Zob. szerzej na temat uprawnienia Marszałka Sejmu do żądania opuszczenia przez posła mównicy w związku z korzystaniem przez niego z trybu zgłoszenia wniosku formalnego w rozważaniach dotyczących wykluczenia posła Armanda Ryfińskiego z posiedzenia Sejmu w dniu 11 IX 2015 r., formułowanych niżej. 
i wskazując podstawę prawną (art. 175 ust. 3 RS), przywołał go do porządku. Następnie marszałek uprzedził posła, że za chwilę powtórzy wskazaną formułę i zostanie on wyprowadzony z sali. W dalszej kolejności nastąpiło przywołanie posła do porządku przez marszałka wraz ze stwierdzeniem, że uniemożliwia on prowadzenie obrad, i wykluczenie posła przez przewodniczącego obradom z posiedzenia Sejmu (z podaniem podstawy prawnej - odpowiednio art. 175 ust. 4 i 5 Regulaminu). Wykluczenie posła z posiedzenia Sejmu nastąpiło po uprzednim stwierdzeniu przez marszałka, iż poseł nadal uniemożliwia prowadzenie obrad. Po podjęciu decyzji o wykluczeniu marszałek poprosił posła o zastosowanie się do jego polecenia i opuszczenie sali, na co poseł zareagował zapowiedzią złożenia odwołania do Komisji Regulaminowej i Spraw Poselskich. Marszałek, przyjąwszy to do wiadomości, po raz kolejny poprosił posła o wykonanie jego polecenia i opuszczenie sali, po czym poinformował Sejm, iż poseł łamie Regulamin, nie stosując się do polecenia Marszałka, całkowicie uprawnionego na podstawie jego przepisów ${ }^{19}$.

Wykluczony z posiedzenia Sejmu poseł podczas obrad Komisji Regulaminowej i Spraw Poselskich w dniu 17 czerwca 2005 r. wskazywał, że w sensie fizycznym nie uniemożliwiał ani nie utrudniał prowadzenia obrad: nie przeszkadzał posłom w ich wypowiedziach, nie utrudniał im poruszania się.

Zauważył ponadto, nawiązując do rozwiązań regulaminowych przyjętych w Niemczech, iż w przedmiocie odwołania posła od decyzji przewodniczącego obradom o wykluczeniu go z posiedzenia parlamentu decydować powinien sam parlament, przy czym komisja może zaopiniować sprawę jego odwołania. Poseł wskazal, że jego zdaniem niedopuszczalna jest sytuacja, w której o uwzględnieniu bądź nieuwzględnieniu odwołania decyduje Prezydium Sejmu, a zatem praktycznie to samo gremium. Dalej uściślił, że to jeden z członków Prezydium Sejmu wydał decyzję, od której do tego organu izby niższej parlamentu on jako poseł się odwołuje. Poseł skonkludował, iż może być on ukarany tylko przez Sejm, a nie przez jego Prezydium.

W sprawie odwołania posła wypowiedziała się również posłanka Hanna Mierzejewska, odnosząc się do jego twierdzeń o nieprzeszkadzaniu swoim zachowaniem w obradach Sejmu i w pracy posłów. Wskazała,

${ }^{19}$ Wypowiedzi na posiedzeniach Sejmu RP IV kadencji, 105. posiedzenie Sejmu w dniu 17 VI 2005 r., http://orka2.sejm.gov.pl/Debata4.nsf (dostęp: 22 X 2016). 
że "(z)achowanie posła jest niezwykle uciążliwe i dekoncentruje posłów występujących z trybuny. Ponadto pokazywane plakaty i napisy nie sa miłe w odbiorze i bardzo stresują zabierających głos [...]". W rezultacie przeprowadzonej dyskusji Komisja przyjęła opinię stwierdzającą bezzasadność złożonego odwołania ${ }^{20}$.

W celu oceny zasadności sformułowanych wyżej argumentów należy podnieść, co następuje. Nawiązując do przytoczonych wcześniej rozważań dotyczących charakteru przesłanki skorzystania przez Marszałka Sejmu z kompetencji porządkowych, to znaczy przesłanki „uniemożliwiania prowadzenia obrad", wskazać trzeba, iż bezsprzecznie przesłankę tę wyczerpuje zachowanie posła polegające na przebywaniu w okolicach mównicy z jakimikolwiek nośnikami treści w formie pisemnej. „Uniemożliwianie prowadzenia obrad" polega tutaj na wprowadzaniu przez posła stresującej osoby przemawiające z trybuny atmosfery i dekoncentrowaniu ich. Wpływa to na poziom merytoryczny wypowiedzi posłów, o który dbać powinien marszałek Sejmu w ramach "prowadzenia obrad".

W konsekwencji stwierdzić należy zatem prawidłowość opinii Komisji.

Rozważyć jednak należy również zagadnienie podmiotu, do którego kierowane powinno być odwołanie posła od decyzji Marszałka Sejmu o wykluczeniu go z posiedzenia Sejmu - czy podmiotem właściwym jest tu Prezydium Sejmu, czy też Sejm. W istocie za obowiązującym rozwiązaniem regulaminowym, kształtującym kompetencję do rozpatrywania wskazanych odwołań po stronie Prezydium Sejmu nie przemawiają żadne istotne argumenty ani natury teoretycznej, ani praktycznej; wręcz przeciwnie - rozwiązanie takie zasługuje na krytykę. $\mathrm{W}$ istocie bowiem o odwołaniu posła od decyzji Marszałka Sejmu o wykluczeniu go z posiedzenia Sejmu współdecyduje tenże Marszałek, a zatem niejako to on współorzeka w postępowaniu odwoławczym w sprawie, w której sam wydał orzeczenie; współkontroluje zatem swoją własną decyzję, co z natury rzeczy wpływać musi na jego bezstronność w toku tej kontroli, a także bezstronność pozostałych członków Prezydium Sejmu, będących przecież wicemarszałkami Sejmu, a więc osobami ściśle z marszałkiem współpracującymi. Argumentacja ta przeważa nad zasadniczym zapewne kontrargumentem obejmującym kolegialność

${ }^{20}$ Posiedzenie numer 135 Komisji Regulaminowej i Spraw Poselskich w dniu 17 VI 2005 r., http://orka.sejm.gov.pl/SQL.nsf/Main4?OpenForm\&RSP (dostęp: $22 \times 2016)$. 
podmiotu rozpatrującego odwołanie posła od decyzji Marszałka Sejmu o wykluczeniu posła z posiedzenia Sejmu, którą to decyzję Marszałek podejmuje jednoosobowo. Za pozostawieniem po stronie Prezydium Sejmu kompetencji do oceny zasadności podjęcia przez Marszałka Sejmu decyzji o wykluczeniu posła z posiedzenia izby niższej parlamentu mogłaby przemawiać okoliczność posiadania przez członków tegoż gremium doświadczenia w prowadzeniu obrad, z czego wynikać może umiejętność trafnej oceny przez nich zachowania poselskiego jako realizującego przesłankę „uniemożliwiania prowadzenia obrad” bądź nie. Wydaje się jednak, że brak takiego doświadczenia po stronie posłów niepełniących funkcji marszałka albo wicemarszałka Sejmu, a będących członkami izby niższej parlamentu, obradującej in pleno, nie wyłącza możliwości podjęcia przez to gremium decyzji trafnej w omawianym zakresie, zwłaszcza w sytuacji, gdy parlamentarzyści oceniają z punktu widzenia wyżej wymienionej przesłanki zachowania, których byli świadkami. Watpliwości wywołuje tu również idea pewnej nadrzędności Prezydium Sejmu nad Marszałkiem, zakodowana w instytucji odwołania (środka odwoławczego) jako takiego, a nieznajdująca uzasadnienia systemowego. Z treści Regulaminu Sejmu nadrzędności takiej (ani jakiejkolwiek hierarchii organów Sejmu) nie da się wywieść. Zapewne wskazówką dla konstruowania jakiegokolwiek stosunku nadrzędności organów Sejmu, także na potrzeby kontroli legalności wykluczeń posłów z posiedzeń Sejmu, mogłyby być tylko przepisy kształtujące hierarchię źródeł prawa, w perspektywie których stwierdzić by należało, że Prezydium Sejmu, w przeciwieństwie do Marszałka Sejmu i samego Sejmu, nie ma zakorzenienia konstytucyjnego. Nadto merytoryczna waga zagadnienia rozpatrywanego na skutek omawianego odwołania, obejmującego $\mathrm{w}$ istocie uczestnictwo deputowanego $\mathrm{w}$ posiedzeniu Sejmu (a zatem jego pracach, co jest w świetle art. 7 ust. 1 zd. 1 RS i art. 3

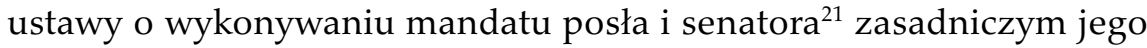
prawem i obowiązkiem), przemawia za rozstrzyganiem tego odwołania przez Sejm, a nie przez jego Prezydium. Co więcej, także względy praktyczne nie przemawiają za utrzymywaniem kompetencji do rozpatrywania odwołań od decyzji Marszałka Sejmu o wykluczeniu posła z posiedzenia izby niższej parlamentu po stronie Prezydium Sejmu, natomiast uzasadniają przyznanie jej Sejmowi in pleno; należy sądzić, że

${ }^{21}$ Ustawa z dnia 9 V 1996 r. o wykonywaniu mandatu posła i senatora (Dz.U. 1996 Nr 73, poz. 350 ze zm.), dalej „u.w.m.p.s.”. 
sformułowanie rozstrzygnięcia przez Sejm w tym przedmiocie w drodze głosowania, po zapoznaniu posłów przez Marszałka Sejmu z treścią odwołania posła i opinią Komisji, a bez przeprowadzania debaty, nie będzie czasochłonne. Odpadałby wówczas problem być może nadmiernego angażowania Sejmu, obradującego na posiedzeniu plenarnym, $\mathrm{w}$ rozpatrzenie i rozstrzyganie odwołania, nieistniejący w przypadku wykonywania tych czynności przez Prezydium Sejmu.

W rezultacie zatem należy się opowiedzieć za zasadnością postulatu modyfikacji treści art. 175 ust. 6 i 7 Regulaminu Sejmu w kierunku zmiany podmiotu posiadającego kompetencję do rozpatrzenia odwołania posła od decyzji Marszałka Sejmu o wykluczeniu posła z posiedzenia Sejmu. Właściwe jest przyznanie tej kompetencji Sejmowi w miejsce Prezydium Sejmu.

\section{Wykluczenie posła Armanda Ryfińskiego z posiedzenia Sejmu w dniu 11 września 2015 r.}

Na posiedzeniu Sejmu w dniu 11 września 2015 r. prezes Rady Ministrów Ewa Kopacz wygłosiła przemówienie na temat problemu napływu do Europy imigrantów z Afryki i Azji w związku z planami Unii Europejskiej ich ulokowania w państwach członkowskich, w tym w Polsce. Po jej wystąpieniu zamiar złożenia wniosku formalnego zgłosił poseł Armand Ryfiński. Wniosek dotyczył ogłoszenia przerwy i zwołania Konwentu Seniorów w celu wprowadzenia do porządku dziennego debaty na temat tego, czy Polska powinna przyjmować imigrantów z Azji i Afryki czy nie, po czym rozpoczął jego uzasadnianie. Ze względu na przekroczenie przez posła czasu wystąpienia marszałek Małgorzata Kidawa-Błońska wyłączyła mikrofon, a poseł opuścił mównicę. Poseł jednak zapisał się do złożenia kolejnego wniosku formalnego. Marszałek udzieliła posłowi głosu w celu jego zaprezentowania, z zastrzeżeniem, że ma to być rzeczywisty wniosek formalny, pod rygorem skierowania sprawy do Komisji Etyki Poselskiej. Uczyniła to przy tym niechętnie, wskazując, że poseł już raz skorzystał z możliwości zabrania głosu w tym trybie, łamiąc przy tym Regulamin (marszałek stwierdziła, że poseł poprzednio nie złożył wniosku formalnego). Gdy poseł rozpoczął swoją wypowiedź, lecz nie sformułował wniosku formalnego, marszałek wyłączyła mikrofon, stwierdzając, że nie jest to wniosek formalny. Poprosiła także posła o opuszczenie mównicy. Następnie kilkukrotnie poseł prosił marszałek 
o umożliwienie mu zgłoszenia wniosku formalnego, przy czym za każdym razem spotykał się z odpowiedzią odmowną. Poseł wnosił także o zwołanie Konwentu Seniorów, czego również odmówiła prowadząca obrady. Gdy w związku z kolejną prośbą posła o stworzenie mu przez marszałek szansy zgłoszenia wniosku formalnego taką szansę od niej otrzymał, poseł przywołał marszałek do porządku, po czym ta ogłosiła przerwę. Po przerwie, gdy marszałek zdecydowała o rozpatrywaniu kolejnego punktu porządku dziennego posiedzenia Sejmu, o głos poprosił znowu poseł Armand Ryfiński. Głosu posłowi marszałek jednak nie udzieliła. Poseł żądał umożliwienia mu złożenia wniosku formalnego, na co marszałek nie wyraziła zgody. Na dalszych kilka próśb w tym przedmiocie ze strony posła marszałek zareagowała kolejno: stwierdzeniem, że poseł zakłóca obrady Sejmu, dwukrotnym przywołaniem go do porządku (za drugim razem ze stwierdzeniem, że uniemożliwia on prowadzenie obrad) i ostatecznie wykluczeniem go z posiedzenia Sejmu - z podaniem podstaw prawnych wskazanych czynności. W dalszej części posiedzenia Sejmu poseł bezpośrednio na ręce marszałek złożył odwołanie od jej decyzji w tym przedmiocie. Z kolei poseł Maciej Mroczek (przewodniczący Komisji Regulaminowej i Spraw Poselskich) złożył wniosek formalny o zarządzenie przerwy i zwołanie Konwentu Seniorów w celu wyjaśnienia sytuacji prawnej posła Armanda Ryfińskiego, który, jak argumentował, został nieprawomocnie wykluczony z posiedzenia Sejmu, przy czym nieprawomocność ta wynika z faktu, że złożył on odwołanie od decyzji w tym przedmiocie. Zdaniem posła sytuacja ta narusza przepisy u.w.m.p.s., stanowiące o obowiązku obecności i czynnego udziału w posiedzeniach Sejmu, a zatem utrudnia posłowi wykonywanie podstawowego obowiązku poselskiego, czyli udziału w głosowaniu. Marszałek wskazała, iż poseł został wykluczony z posiedzenia Sejmu, natomiast poseł Maciej Mroczek stwierdził, iż nastąiło to nieprawomocnie i obowiązuje tryb odwołania. Marszałek odpowiedziała, że na tamtą chwilę sprawa należy do Komisji Regulaminowej i Spraw Poselskich ${ }^{22}$.

Na posiedzeniu Komisji w dniu 11 września 2015 r. poseł Armand Ryfiński wskazywał na okoliczność, że w istocie jego zachowanie nie wypełniało przesłanki „uniemożliwiania prowadzenia obrad”, gdyż nie

${ }^{22}$ Sprawozdanie stenograficzne z 99. posiedzenia Sejmu Rzeczypospolitej Polskiej w dniu 11 IX 2015 r. (trzeci dzień obrad), Warszawa 2015, s. 312-313, 316, 318-319, 324, 336-337, http://orka2.sejm.gov.pl/StenoInter7.nsf/0/918C5EBC04164B84C1257EBD00791018/\%24File/99_c_ksiazka.pdf (dostęp: 22 X 2016). 
wdzierał się on na mównicę siła, z jego strony nie padały żadne zwroty, które mogłyby być uznane za nielicujące z powagą Sejmu albo zakłócające porządek obrad. Poseł wskazywał, że chodziło mu tylko i wyłącznie o złożenie i dokończenie formułowania wniosku formalnego. Wskazywał również na to, że marszałek po podjęciu decyzji o jego wykluczeniu z posiedzenia Sejmu i wniesieniu przez niego odwołania powinna przerwać obrady, by umożliwić rozstrzygnięcie środka odwoławczego przez Prezydium Sejmu, po zaopiniowaniu go przez Komisję Regulaminową i Spraw Poselskich. Powoływał się na dotychczasową tego rodzaju praktykę stosowaną przez przewodniczących obradom. Poseł wskazywał ponadto, że takie zachowanie Marszałka związane jest z zagadnieniem prawomocności jego decyzji o wykluczeniu posła z posiedzenia Sejmu. W jego ocenie w przypadku wniesienia odwołania decyzja jest nieprawomocna, a uprawomocnia się dopiero wówczas, gdy w przedmiocie odwołania decyzję podejmie Prezydium Sejmu. W przypadku gdy decyzja o wykluczeniu posła z posiedzenia Sejmu nie jest prawomocna, nie można pozbawiać posła uprawnienia czynnego uczestnictwa w pracach izby niższej parlamentu. W zaistniałej sytuacji, skoro obrady trwały w dalszym ciągu, naruszeniem prawa było uniemożliwienie mu realizacji wskazanego uprawnienia. Jednocześnie poseł zaznaczył, że po wykluczeniu do pewnego momentu brał on czynny udział w posiedzeniu Sejmu, choć w świetle Regulaminu nie miał takiego prawa, co było kolejnym naruszeniem przepisów przez marszałek.

Z kolei legislator w Biurze Legislacyjnym Kancelarii Sejmu Przemysław Sadłoń wskazywał, że brak po stronie posła zachowań nielicujących z powagą Sejmu nie wyklucza wypełnienia przesłanki „uniemożliwiania prowadzenia obrad". Odnosząc się natomiast do skutku podjęcia przez Marszałka Sejmu decyzji o wykluczeniu posła z posiedzenia Sejmu, zauważył on, iż skutkiem tym jest konieczność opuszczenia przez posła sali posiedzeń Sejmu. Jeśli poseł tego nie uczyni, to Marszałek Sejmu ma obowiązek zarządzenia przerwy w obradach Sejmu, która powinna być wykorzystana na to, by poseł opuścił salę jego posiedzeń. Legislator wskazywał, że omawiany wyżej skutek decyzji Marszałka o wykluczeniu posła z posiedzenia Sejmu następuje od razu, a inną kwestią jest uprawnienie posła do odwołania się od wskazanej decyzji Marszałka do Prezydium Sejmu. Zaakcentował, że wskazane odwołanie nie zawiesza skutku w postaci konieczności opuszczenia przez posła posiedzenia Sejmu. Jego zdaniem decyzji o wykluczeniu posła z posiedzenia Sejmu nie można rozpatrywać w kategoriach prawomocności bądź 
nieprawomocności. W dalszej części posiedzenia Komisji wskazywał on także, że w istocie poseł ma prawo odwołać się od decyzji Marszałka o jego wykluczeniu z posiedzenia Sejmu do jego Prezydium, a Prezydium rozstrzyga sprawę "niezwłocznie” po zasięgnięciu opinii Komisji. „Niezwłoczność" nie oznacza jednak, że posiedzenie Sejmu należy przerwać po to, by zwołać posiedzenie Prezydium Sejmu dla rozstrzygnięcia odwołania, o którym mowa wyżej. Świadczy o tym treść art. 175 ust. 6 zd. 2 RS, zgodnie z którym wskazano, że do czasu ostatecznego rozstrzygnięcia sprawy poseł nie bierze udziału w posiedzeniu Sejmu. Dopuszczalna jest zatem sytuacja, w której mimo wniesienia odwołania obrady trwają nadal, przy czym poseł nie może w nich uczestniczyć. Poseł może z powrotem brać udział w posiedzeniu Sejmu, o ile nadal ono trwa, tylko wtedy, gdy Prezydium Sejmu uchyli decyzję Marszałka o wykluczeniu posła z posiedzenia Sejmu na skutek rozpatrzenia jego odwołania od tej decyzji. Legislator odniósł się także do dwóch innych kwestii. Wskazał, iż kompetencja Marszałka przewidziana w art. 175 Regulaminu Sejmu ma charakter szczególny wobec uprawnienia (i obowiązku) posła do brania czynnego udziału w posiedzeniach Sejmu. Zauważył też, że przepisy Regulaminu Sejmu nie regulują w sposób ścisły kwestii tego rodzaju, jak należy formułować wniosek formalny, tzn. kiedy ów wniosek należy sformułować - czy ma to nastąić na początku wypowiedzi posła (przed jego uzasadnieniem), czy też na jej końcu (po jego uzasadnieniu). W rezultacie przeprowadzonej dyskusji Komisja przyjęła opinię stwierdzającą słuszność wykluczenia posła przez marszałek z posiedzenia Sejmu ${ }^{23}$.

W celu oceny zasadności sformułowanych wyżej argumentów należy podnieść, co następuje. Odnosząc się do kwestii wypełnienia przez posła przesłanki „uniemożliwiania prowadzenia obrad", zauważyć wypada, że zachowaniem Marszałka Sejmu niezgodnym z Regulaminem jest sytuacja, w której przewodniczący obradom nakazuje posłowi opuszczenie mównicy w regulaminowym czasie trwania jego wystąpienia, mającego na celu zgłoszenie wniosku formalnego. Na zasadzie art. 184 ust. 1 RS Marszałek Sejmu udziela bowiem głosu m.in. poza porządkiem dziennym posiedzenia jedynie dla zgłoszenia wniosku formalnego, który Sejm rozstrzyga m.in. po wysłuchaniu wnioskodawcy (art. 184 ust. 5 RS). W świetle art. 184 ust. 8 RS ma on czas do dwóch minut

${ }^{23}$ Posiedzenie numer 114 Komisji Regulaminowej i Spraw Poselskich w dniu 11 IX 2015 r., http://orka.sejm.gov.pl/zapisy7.nsf/0/2DCDB27E77544F71C1257EC200304576/\%24File/0507007.pdf (dostęp: 22 X 2016). 
na wypowiedzenie się $\mathrm{w}$ przedmiocie wskazanego wniosku. Z treści przytoczonych przepisów wynika, że poseł, któremu przewodniczący obradom udzielił głosu w celu zgłoszenia wniosku formalnego, ma prawo do wypowiedzenia się w tym przedmiocie w czasie dwóch minut, przy czym sformułowanie tego wniosku może nastąpić na początku albo na końcu tego czasu. Przepisy nie precyzują tego, czy sam wniosek ma nastąpić wcześniej niż jego uzasadnienie czy też odwrotnie, a zatem dopuszczalne są obie możliwości. Może też dojść do sytuacji, w której we wskazanym trybie poseł nie złoży żadnego wniosku o charakterze formalnym, a wypowie się (w szczególności zawnioskuje) merytorycznie (wbrew treści art. 184 ust. 2 RS, stanowiącego o katalogu dopuszczalnych wniosków formalnych). Wtedy jego prawo do wypowiedzi jako takiej wynika $z$ tego tylko, iż zgłosił on chęć przedstawienia wniosku formalnego. W każdej z tych sytuacji Marszałek Sejmu może żądać opuszczenia przez posła mównicy jedynie w przypadku przekroczenia przez niego czasu przeznaczonego na zgłoszenie wniosku formalnego, ale już nie $\mathrm{w}$ regulaminowym czasie wystąpienia poselskiego $\mathrm{w}$ trybie art. 184 ust. 1 RS.

Wskazać przy tym należy, że Marszałek nie może posłowi, w sytuacji jego występowania merytorycznego w trybie zgłoszenia wniosku formalnego, zwrócić uwagi przywołaniem "do rzeczy" (art. 175 ust. 2 RS) i w konsekwencji odebrać głos. Wskazany sposób zwrócenia uwagi dotyczy jedynie wypowiedzi w ramach kwestii merytorycznych, objętych poszczególnymi punktami porządku dziennego posiedzenia Sejmu.

Niezależnie od powyższych ustaleń zaznaczyć jednak trzeba, że nawet w sytuacji, w której Marszałek Sejmu w sposób niezgodny z Regulaminem Sejmu żąda od posła opuszczenia mównicy w regulaminowym czasie jego wystąpienia w trybie art. 184 ust. 1 RS, brak zastosowania się przez posła do tego żądania i w konsekwencji okupowanie (blokowanie) przez niego mównicy stanowi przejaw „uniemożliwiania prowadzenia obrad". Takie zachowanie poselskie samo w sobie odpowiada bowiem wskazanej przesłance.

Odnosząc się do kwestii skutków podjęcia przez Marszałka Sejmu decyzji o wykluczeniu posła z posiedzenia Sejmu, wskazać należy, że zasadniczy jej skutek wynika expressis verbis z treści art. 175 ust. 5 zd. 1 in fine Regulaminu Sejmu. Wykluczony przez Marszałka Sejmu poseł obowiązany jest zatem do opuszczenia sali posiedzeń Sejmu. Wskazać przy tym należy, iż przerwa w obradach, o której mowa w art. 175 ust. 5 zd. 2 Regulaminu, może być zarządzona przez Marszałka jedynie 
w celu doprowadzenia do sytuacji, w której poseł opuści salę posiedzeń izby niższej parlamentu. Przemawia za takim wnioskiem treść art. 175 ust. 5 zd. 2 Regulaminu Sejmu, w którym uzależnia się zarządzenie przez Marszałka Sejmu przerwy w obradach od zaniechania przez posła obowiązku opuszczenia sali posiedzeń Sejmu po jego wykluczeniu z posiedzenia. Osobnym problemem jest zakres środków, jakimi dysponuje Marszałek Sejmu dla zrealizowania podczas przerwy wskazanego wyżej celu ${ }^{24}$. Zarządzenie przez Marszałka przerwy w obradach, w celu określonym powyżej, powinno przy tym nastąpić zarówno w przypadku pozostawania posła na sali posiedzeń Sejmu bezpośrednio po podjęciu przez Marszałka decyzji o jego wykluczeniu z posiedzenia izby niższej parlamentu, jak i w przypadku jego powrotu do tej sali w czasie trwania posiedzenia Sejmu, z którego został on przez przewodniczącego obradom wykluczony.

Zgodzić należy się natomiast z poglądem, że celem przerwy w obradach zarządzonej przez Marszałka Sejmu na podstawie art. 175 ust. 5 zd. 2 RS nie jest rozpatrzenie odwołania posła od decyzji przewodniczącego obradom o wykluczeniu posła z posiedzenia Sejmu. Przemawia za tym wnioskiem, oprócz treści art. 175 ust. 5 zd. 2 Regulaminu, wyłożonej wyżej w zakresie celu zarządzenia przez Marszałka omawianej przerwy, także treść art. 176 ust. 6 zd. 2 Regulaminu Sejmu, z którego wprost wynika, iż niedopuszczalne jest branie przez posła udziału w posiedzeniu Sejmu podczas rozpatrywania odwołania przez Prezydium Sejmu. Posiedzenie Sejmu trwa zatem nadal mimo wniesienia przez posła odwołania od decyzji Marszałka o wykluczeniu go z posiedzenia Sejmu, przy czym kontynuacja tego posiedzenia to także kontynuacja jego obrad.

W tym kontekście zarządzenie przez Marszałka przerwy w obradach nie ma także związku z czasem („niezwłocznością”) rozpatrywania odwołania.

Odnieść wypada się również do charakteru prawnego decyzji Marszałka o wykluczeniu posła z posiedzenia Sejmu, skutkującej

\footnotetext{
${ }^{24}$ W szczególności chodzi tu o problem dopuszczalności użycia Straży Marszałkowskiej przez przewodniczącego obradom izby w celu zrealizowania jego decyzji obejmującej wykluczenie posła z posiedzenia Sejmu (zob. szerzej: A. Szmyt, W sprawie podstawy prawnej działań Straży Marszałkowskiej w celu wykonania decyzji Marszałka Sejmu o wykluczeniu posta z posiedzenia, Ekspertyzy i Opinie Prawne 2(47)02, Biuletyn Biura Studiów i Ekspertyz Kancelarii Sejmu, s. 16-19; idem, Elementy praktyki sejmowej..., s. 97-100, 102; J. Mordwiłko, Możliwość użycia przez Marszałka Sejmu Straży Marszałkowskiej w celu wykonania decyzji o wykluczeniu posła z posiedzenia, Ekspertyzy i Opinie Prawne 2(47)02, Biuletyn Biura Studiów i Ekspertyz Kancelarii Sejmu, s. 20-26.
} 
obowiązkiem opuszczenia przez posła sali posiedzeń Sejmu, w sytuacji dopuszczalności wniesienia przez posła od tej decyzji odwołania. Wskazana decyzja, tj. jej skutek, ma zostać niezwłocznie zrealizowany, niezależnie od kontroli jej zasadności przez inny niż Marszałek organ Sejmu, w wyniku której realizacja ta (co do zasady - przy założeniu nieuwzględnienia odwołania i poza przypadkami niewniesienia odwołania) powinna następować. Jeśli posłużyć się dla zobrazowania charakteru prawnego omawianej decyzji terminologią prawa postępowania cywilnego, to można by tu mówić o pewnej quasi-natychmiastowej wykonalności tej decyzji, niezależnej od jej quasi-prawomocności, ze względu na treść art. 175 ust. 5 zd. 1 in fine Regulaminu Sejmu i fakt istnienia trybu odwoławczego od niej. W oczywisty sposób powyższa konstrukcja uzasadniona jest koniecznością zapewnienia sprawności funkcjonowania Sejmu.

Wskazać również na koniec trzeba, że kompetencja porządkowa Marszałka, wyrażona w art. 175 ust. 5 Regulaminu, stanowi lex specialis względem przepisów art. 7 ust. 1 zd. 1 RS i art. 3 u.w.m.p.s., stanowiących o uprawnieniu i obowiązku posła w zakresie obecności i czynnego udziału w posiedzeniach izby niższej parlamentu. Biorąc więc pod uwagę zasadę lex specialis derogat legi generali, stwierdzić należy, że fakt skorzystania przez Marszałka ze wskazanej wyżej kompetencji nie ma charakteru bezprawnego.

W rezultacie stwierdzić należy prawidłowość opinii Komisji.

\section{Podsumowanie}

Dokonane w toku prac Komisji Regulaminowej i Spraw Poselskich (w trybie art. 175 ust. 6 Regulaminu Sejmu) analizy okoliczności skorzystania przez Marszałka Sejmu z uprawnienia do wykluczenia posła z posiedzenia Sejmu mają różnorodny charakter. Jedne dotyczą problematyki prawidłowości zakwalifikowania danego zachowania poselskiego jako "uniemożliwiającego prowadzenie obrad", co jest przesłanką wykluczenia posła z posiedzenia Sejmu, inne zagadnień prawidłowości zastosowania przez przewodniczącego obradom przewidzianej w art. 175 Regulaminu procedury zmierzającej do tego wykluczenia, a kolejne kwestii szeroko pojętych konsekwencji omawianego wykluczenia.

Zauważyć należy, w świetle opinii formułowanych przez Komisję w trybie art. 175 ust. 6 Regulaminu Sejmu, że jej analizy w wyżej 
wskazanych obszarach obejmowały przyjęcie przez nią jako zasadnych argumentacji na rzecz: (1) kwalifikacji jako „uniemożliwiania prowadzenia obrad" zachowań poselskich obejmujących nieopuszczanie (okupowanie, blokowanie) mównicy, jak również przebywanie w okolicach mównicy z jakimikolwiek nośnikami treści w formie pisemnej; (2) braku konieczności dla wykluczenia posła z posiedzenia Sejmu uprzedniego zwrócenia mu uwagi przywołaniem go "do rzeczy” związanym z faktem odbiegania przez niego w jego wystapieniu od przedmiotu obrad określonego w porządku dziennym posiedzenia Sejmu; (3) braku konieczności wskazania przez Marszałka posłowi podstawy prawnej (regulaminowej) skorzystania przez niego z kompetencji do wykluczenia posła z posiedzenia Sejmu dla skuteczności zastosowania tego środka, a także (4) przyjęcia, że wniesienie przez posła odwołania do Prezydium Sejmu od decyzji Marszałka o jego wykluczeniu z posiedzenia Sejmu nie ma wpływu na skutek tego wykluczenia, jakim jest obowiązek natychmiastowego opuszczenia przez posła sali posiedzeń Sejmu - oraz odrzucenie argumentacji zmierzających w przeciwnym kierunku.

Wyrażone w treści artykułu oceny zasadności wskazanych argumentacji dają podstawy do przyjęcia twierdzeń o prawidłowości opinii formułowanych przez Komisję w trybie art. 175 ust. 6 Regulaminu Sejmu.

Podobnie dokonana w opracowaniu ocena zasadności zgłoszonej w toku prac Komisji argumentacji na rzecz modyfikacji treści art. 175 ust. 6 i 7 Regulaminu Sejmu w kierunku zmiany podmiotu posiadającego kompetencję do rozpatrzenia odwołania posła od decyzji Marszałka Sejmu o wykluczeniu posła z posiedzenia Sejmu z Prezydium Sejmu na Sejm (tzn. argumentacji obejmującej de facto tożsamość podmiotu podejmującego wskazaną decyzję i podmiotu rozstrzygającego w przedmiocie odwołania od niej) w istocie przemawia za zasadnością postulatu obejmującego taką modyfikację.

\section{EXCLUSION OF A MEMBER OF PARLIAMENT FROM THE SEJM SITTING (ARTICLE 175 CLAUSE 5 OF THE SEJM RULES) IN THE LIGHT OF THE WORK OF THE RULES AND DEPUTIES' AFFAIRS COMMITTEE}

\section{S u m mary}

This article provides an assessment of the correctness of the opinions formulated by the Rules and Deputies' Affairs Committee about deputies' appeals to the Presidium of the Sejm against the Marshal of the Sejm's decisions on their exclusions 
from the sittings of the Sejm. The assessment has been formulated on the basis of an analysis of the legitimacy of the arguments raised in the course of five sittings of the Committee. These arguments are related to problems associated with the classification of certain deputies' behaviours as (i) 'preventing conducting of the sitting', which is the premise of deputies' exclusion from the sitting of the Sejm, (ii) the correctness of application by the Marshal of the Sejm of the procedure leading to such exclusion and (iii) its consequences. The assessment of the correctness of the abovementioned arguments and its presentation is preceded by the description of the event occurred during the sitting of the Sejm and a reference to the content of Article 175 of the Standing Orders of the Sejm. The first conclusion drawn based on the analysis of the above is that the opinions issued by the Committee are correct.

Another assessment concerned the legitimacy of the postulate formulated during one of the sittings of the Committee to change the body competent to recognise deputies' appeals against the Marshal of the Sejm's decisions on their exclusions from the sittings of the Sejm and move such competence should from the Sejm's Presidium to the Sejm itself. The assessment of the legitimacy of that postulate has been based on the assessment of the legitimacy of the argument for such a solution, raised during the sitting in question of the Committee. The other conclusion drawn is that this postulate was legitimate.

Keywords: exclusion - Marshal - deputy - parliament - committee 